\title{
Determinants of Pancreatic Islet Development in Mice and Men: A Focus on the Role of Transcription Factors
}

\author{
Chia-Lei Vivian Lin Patricia Myriam Vuguin \\ Department of Pediatrics, Pediatric Endocrinology, The Children's Hospital at Montefiore, Albert Einstein \\ College of Medicine, Bronx, N.Y., USA
}

\section{Key Words}

Endocrine differentiation - Pancreas development •

Transcription factors $\cdot$ Beta cells

\begin{abstract}
The development of the endocrine pancreas is regulated by several cell-matrix interactions that generate a diverse array of intracellular signals determining the progression of a multipotent progenitor to a mature endocrine cell. This process involves interactions between the epithelium, mesenchyma, and endothelial cells. Later in development, coordinated signaling contributes to the maintenance of the differentiated endocrine cell phenotype. It has been demonstrated that key factors as well as the sequence of events involved in mouse pancreatic development is conserved in humans. This review will discuss our current knowledge in mouse as well as human pancreatic development and highlights some important transcription factors associated with human disease.
\end{abstract}

Copyright $\odot 2012$ S. Karger AG, Basel

\section{Introduction}

The mammalian pancreas is a mixed exocrine and endocrine gland that produces digestive enzymes and hormones. The enzymes are produced by cells of the exocrine portion, while the hormones are synthesized by cells clus- tered in the islets of Langerhans. The islet secretion profile is comprised of insulin (beta cells), glucagon (alpha cells), somatostatin (delta cells), ghrelin (epsilon cells) and pancreatic polypeptide (PP cells). These endocrine cells play a central role in glucose homeostasis. Insulin released from beta cells after a meal promotes the uptake of glucose into target organs, such as skeletal muscle. The action of insulin is counterbalanced by glucagon, a hormone produced by alpha cells that acts on the liver to stimulate glycogenolysis and gluconeogenesis [1]. Diabetes mellitus results from a dysfunction in insulin and glucagon signaling. In type 1 diabetes, beta cells are progressively destroyed by autoimmunity, whereas in type 2 diabetes, the pancreatic beta cell is unable to compensate for the metabolic demand of the peripheral tissues. For millions of people suffering from type 1 diabetes, beta-cell replacement therapy offers a possible treatment. Unfortunately, this approach has been hampered by a scarcity of cells for transplantation and the preexisting autoimmunity which destroys the transplants. Today, a promising solution to this problem is directing the differentiation of stem cells into beta cells. However, the pluripotency of stem cells, while potentially advantageous, poses a significant challenge. In order to overcome this challenge, it is necessary to understand how a beta cell matures under normal circumstances. For example, progenitor cells follow an endocrine fate under the influence of a complex network of genes and hormones that operate before and after birth

\section{KARGER}

Fax +4161306 1234

E-Mail karger@karger.ch

www.karger.com (c) 2012 S. Karger AG, Basel

$1663-2818 / 12 / 0774-0205 \$ 38.00 / 0$

Accessible online at:

www.karger.com/hrp
Patricia M. Vuguin, MD, MSc

Department of Pediatrics

The Children's Hospital at Montefiore Medical Center

111 E 210th Street, Bronx, NY 10467 (USA)

Tel. +1 718920 4664, E-Mail patricia.vuguin@einstein.yu.edu 
Fig. 1. Schematic model representing the transcription factors implicated in the specification of the endocrine pancreas based on the temporal expression and the phenotypic consequences of specific gene deletions.

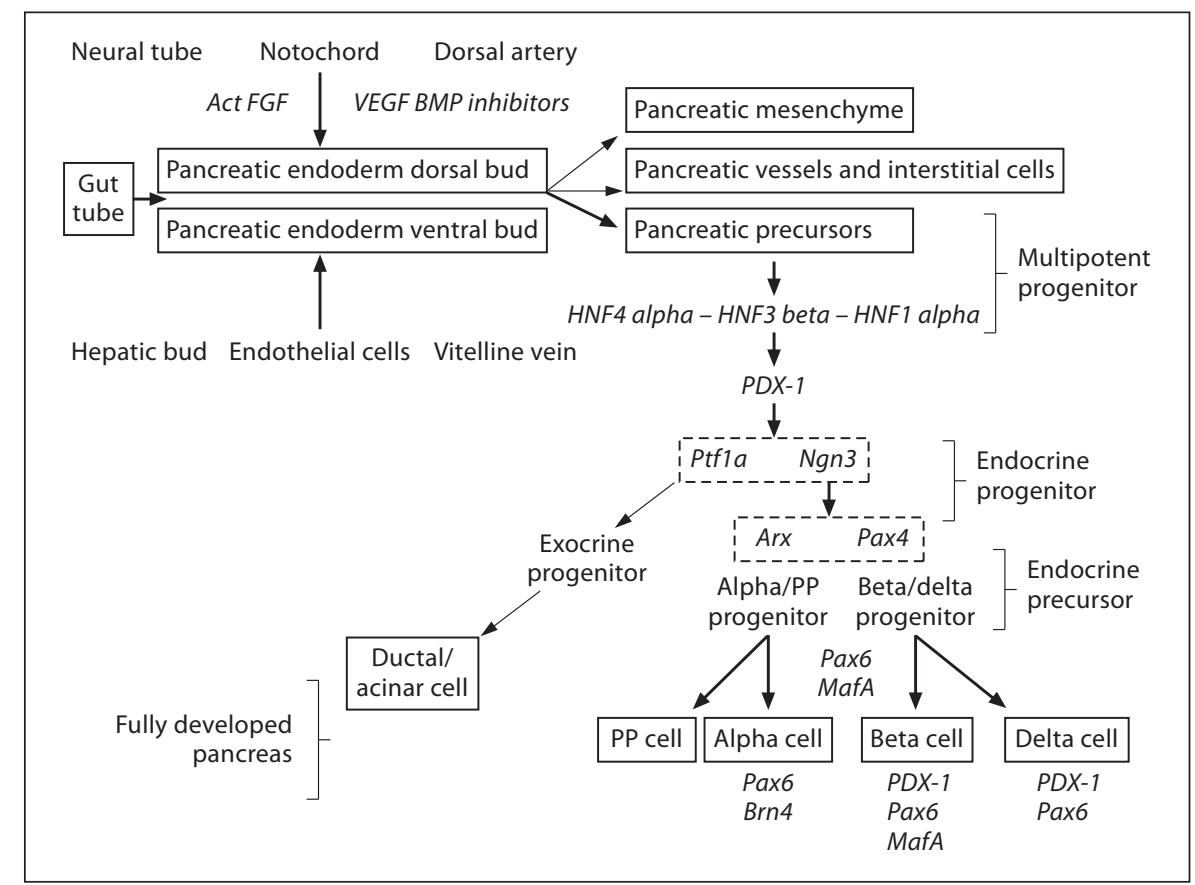

(fig. 1; table 1). Advances have also been made in defining the role of environmental factors in endocrine pancreas development [2]. Nutrients such as glucose and oxygen are necessary for endocrine cell differentiation [3]. As a result, the identification of factors that influence the growth and differentiation of endocrine precursor cells has important implications in the treatment of diabetes. Pancreatic development seems to be conserved among species (rodent, sheep, and human), thus the rodent model (mouse) has been a powerful tool for understanding pancreatic development. This has allowed for the elucidation of signals and the development of potential tools to improve the in vitro generation of functional beta cells from stem and/or progenitor cells. The following review will discuss our current knowledge of the stages of pancreatic development including differentiation, proliferation, and maturation and compares this process between mouse and human with particular attention to the role of transcription factors in endocrine cell development.

\section{Pancreatic Morphogenesis}

The pancreas derives from two independent thickening or 'anlage' dorsally and ventrally of the endodermal germ layer. However, the development of each anlage is not identical and requires different signaling from the surrounding tissues. The dorsal bud develops in the proximity of the notochord and the splanchnic mesenchyme, which forms the dorsal aorta. Some of the signals involved are activin, fibroblast growth factor (FGF), transforming growth factor-beta (TGF $\beta$ ), retinoid acid, vascular endothelial growth factor, bone morphogenetic protein inhibitors, and hedgehog-type ligands. The ventral bud, initially developing as two independent endodermal regions, grows in close contact with the liver and bile duct epithelium, and is brought together at the time of gut tube closing (fig. 1). The epithelium then invades the surrounding mesenchyme, which will signal proliferation in the adjacent epithelial buds of the pancreatic primodium. Subsequently, the invasion is followed by branching, differentiation, and maturation of the pancreatic primordium. Consequently, the microlumens coalesce to form a continuous lumen around which the ductal network will develop, leading to the formation of the ductal tree $[4,5]$. Intercellular signaling through TGF $\beta$, Notch, FGF, Wnt, and Hedgehog signaling are then crucial for proper endocrine and exocrine pancreatic development $[6,7]$. Similar to humans, alpha cells are the first cells to appear in fetal rodent pancreas. Alpha cells are found at embryonic day (e) 9.5, followed by beta cells at e13.5, delta cells at e15, and PP cells at e18 (fig. 2; table 1) [8]. 
Table 1. Critical period of pancreatic development in mouse

\begin{tabular}{|c|c|c|c|}
\hline Embryonic day & Occurrence & Morphological changes & Gene expression \\
\hline e8-8.5 & Primary transition & No visible pancreatic epithelium & $\begin{array}{l}\text { Isl } 1 \text { in dorsal mesenchyme; Cdk } 4 \text { expansion } \\
\text { of pancreatic tissue }\end{array}$ \\
\hline e8.5-9.5 & Embryo rotation & Closure of the gut tube & PDX-1 activation \\
\hline e9.5-10 & Budding & $\begin{array}{l}\text { Ventral bud appears; pancreatic } \\
\text { epithelium evagination; presence } \\
\text { of glucagon cells }\end{array}$ & $\begin{array}{l}\text { Ngn3, Nkx6.1, Pax6, Isl1, Hes1, HNF6, } \\
\text { NeuroD }\end{array}$ \\
\hline e10.5-11 & & $\begin{array}{l}\text { Epithelial evagination branching } \\
\text { and innervation; presence of co- } \\
\text { expressing glucagon insulin cells }\end{array}$ & Ptf1 \\
\hline $\mathrm{e} 12$ & Branching & & \\
\hline e18 & & PP cells appear & \\
\hline Postnatal & Growth & $\begin{array}{l}\text { Endocrine and exocrine growth; } \\
\text { formation of acini }\end{array}$ & \\
\hline
\end{tabular}

\section{Transcription Factors}

Most of the understanding about endocrine pancreatic development has arisen from animal models in which several transcription factors have been genetically manipulated (table 2). The array of transcription factors important for pancreas development can be broken down and classified according to their expression pattern: (1) transcription factors found in early non-hormone progenitor cells [e.g. neurogenin 3 (Ngn3)]; (2) transcription factors found in cells that produce each of the endocrine hormones [e.g. NeuroD1, islet-1 (Isl1), and paired box 6 (Pax6)], and (3) transcription factors found in a specific hormone-producing cell type [e.g. Nkx6.1, Nkx2.2, Pax4, Arx, and brain 4 (Brn4)] [9].

\section{Transcription Factors Found in Early Non-Hormone}

Progenitor Cells

The pancreatic buds contain undifferentiated precursor cells that are specified towards either the endocrine or exocrine lineage. All cells that derive from the endoderm - endocrine, exocrine, and ductal cells - have been shown to express duodenal homeobox factor-1 (PDX-1) (fig. 1, 2) [10]. The Notch signaling system is critical for the decision between endocrine and progenitor/exocrine fates in the developing pancreas [11]. Similarly, Sox9 in conjunction with the Notch pathway maintains the progenitor state [12]. Bone morphogenetic protein- 4 also blocks the differentiation of progenitor cells, instead promoting their proliferation [13]. A pair of opposing transcription factors, Ptfla and Ngn3, acts as the first fate-determining factors in the branching of pancreatic progenitors into the endocrine and exocrine pancreas. The pair of opposing transcription factors 'Ptfla-Ngn3' directs this differentiation (fig. 1) [14]. Ptfla gives rise to exocrine cells, while Ngn3 drives pancreatic precursors towards the endocrine cell fate [15-17]. During the differentiation of islet cells, Ngn3 regulates the cell cycle; its down-regulation allows the mature islet cell population to expand [18]. Cyclin-dependent kinase 4 and its downstream transcription factor E2f1 regulate the activation of Ngn3, increasing the pool of endocrine precursors [19]. Downstream of Ngn3 is Rfx6, which has been shown to play a crucial role in the development, maturation, and function of endocrine cell lines [20].

It has been proposed that endocrine cells develop directly from a dividing Ngn3+/PDX-1+/Nkx6.1+/Ki-67+ 
Table 2. Role of transcription factors associated with mouse and human pancreatic development

\begin{tabular}{|c|c|c|c|c|c|}
\hline Factor & $\begin{array}{l}\text { Day of } \\
\text { onset }\end{array}$ & Role & Mouse phenotype & Human phenotype & Ref. \\
\hline$H l x b 9$ & e8 & $\begin{array}{l}(+) \text { notochord, dorsal gut, and ventral } \\
\text { endoderm; required for dorsal } \\
\text { pancreatic development }\end{array}$ & $\begin{array}{l}-/- \text { failure to develop dorsal pancreatic } \\
\text { lobe; small islet cells and decreased } \\
\text { number of beta cells }\end{array}$ & & {$[72]$} \\
\hline$P D X-1$ & e8.5 & $\begin{array}{l}(+) \text { in pancreatic buds and beta and } \\
\text { delta cells; regulates beta-cell function }\end{array}$ & $\begin{array}{l}\text {-/-: failure of pancreatic bud to expand, } \\
\text { hyperglycemia and early death } \\
+/- \text { normal pancreatic development with } \\
\text { diabetic phenotype }\end{array}$ & $\begin{array}{l}\text { +/-: MODY } 4 \text { and T2DM } \\
\text {-/-: pancreatic agenesis }\end{array}$ & $\begin{array}{l}{[34,73,} \\
74]\end{array}$ \\
\hline Isl1 & e9 & $\begin{array}{l}\text { (+) dorsal pancreatic mesenchyme and } \\
\text { exocrine pancreas; required for dorsal } \\
\text { exocrine and all endocrine } \\
\text { development }\end{array}$ & $\begin{array}{l}\text {-/-: no dorsal pancreatic mesenchyme and } \\
\text { exocrine cells; loss of differentiated islet } \\
\text { cells }\end{array}$ & $\begin{array}{l}+/-: \text { non-sense mutation } \\
(\mathrm{Q} 310 \mathrm{X}) \text { found in } 1 \text { diabetic } \\
\text { patient }\end{array}$ & {$[75,76]$} \\
\hline Sox9 & e9 & $\begin{array}{l}(+) \text { in PDX-1+ progenitors; } \\
\text { maintains Notch signaling }\end{array}$ & $\begin{array}{l}\text {-/-: increase in apoptosis and decrease in } \\
\text { proliferation of PDX-1 progenitors } \\
+/- \text { glucose intolerance }\end{array}$ & & {$[12,77]$} \\
\hline$N k x 2.2$ & e9.5 & $\begin{array}{l}(+) \text { in undifferentiated pancreatic } \\
\text { epithelium and endocrine progenitors } \\
\text { followed by }(+) \text { in alpha, beta, and PP } \\
\text { cells; maintains normal beta-cell } \\
\text { function }\end{array}$ & $\begin{array}{l}\text {-/-: lack of beta cells, decreased number of } \\
\text { alpha and PP cells; large population of } \\
\text { ghrelin + cells; severe hyperglycemia, early } \\
\text { death }\end{array}$ & & {$[23]$} \\
\hline Pax4 & e9.5 & $\begin{array}{l}(+) \text { in endocrine progenitors; essential } \\
\text { for beta- and delta-cell maturation }\end{array}$ & $\begin{array}{l}\text {-/-: reduction in beta- and delta-cell } \\
\text { numbers, increase in alpha and ghrelin } \\
\text { cells }\end{array}$ & & {$[80,81]$} \\
\hline NeuroD1 & e9.5 & $(+)$ in developing and mature beta cells & $\begin{array}{l}-/- \text { : reduction in beta-cell number, failure } \\
\text { to develop mature islets; hyperglycemia, } \\
\text { and perinatal death }\end{array}$ & $\begin{array}{l}\text {-/-: neonatal diabetes } \\
\text { +/-: MODY6 }\end{array}$ & {$[82,83]$} \\
\hline Ptfla & e10 & $\begin{array}{l}(+) \text { in pancreatic progenitors; } \\
\text { regulates exocrine differentiation }\end{array}$ & $\begin{array}{l}\text {-/-: p48 (Ptfla subunit): lack of exocrine } \\
\text { pancreas with relocation of endocrine } \\
\text { pancreas to the spleen; } \\
\text { Hypomorphic mutation: pancreatic } \\
\text { hypoplasia, glucose intolerance, and } \\
\text { mis-specification of progenitors; delay of } \\
\text { branching morphogenesis and exocrine } \\
\text { differentiation }\end{array}$ & $\begin{array}{l}\text { Permanent neonatal diabetes } \\
\text { associated with pancreatic } \\
\text { agenesis }\end{array}$ & {$[86-88]$} \\
\hline$N k x 6.1$ & $\mathrm{e} 10.5$ & $\begin{array}{l}\text { (+) in Ngn } 3+\text { endocrine precursors, } \\
\text { later restricted to beta cells; necessary } \\
\text { for second wave of beta-cell } \\
\text { differentiation }\end{array}$ & $\begin{array}{l}\text {-/-: embryos with normal pancreas size, } \\
\text { but reduced islet size with a reduction in } \\
\text { beta-cell number }\end{array}$ & & {$[26]$} \\
\hline$M a f B$ & $\mathrm{e} 12.5$ & $\begin{array}{l}(+) \text { alpha and beta cells, becomes } \\
\text { restricted to alpha cells; required for } \\
\text { beta-cell terminal differentiation }\end{array}$ & $\begin{array}{l}\text {-/-: reduced number of alpha and beta } \\
\text { cells throughout development; production } \\
\text { of beta cells delayed until e13.5 with the } \\
\text { onset of MafA }\end{array}$ & & {$[89]$} \\
\hline
\end{tabular}

T2DM = Type 2 diabetes mellitus; $-/-=$ homozygous; $+/-=$ heterozygous; $(+)=$ expression; MODY = maturity-onset diabetes of the young. 
a

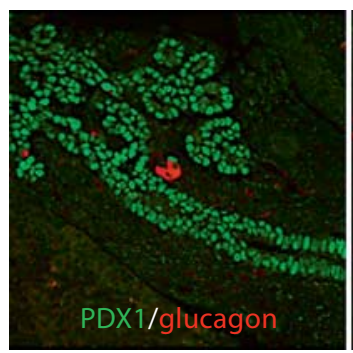

c

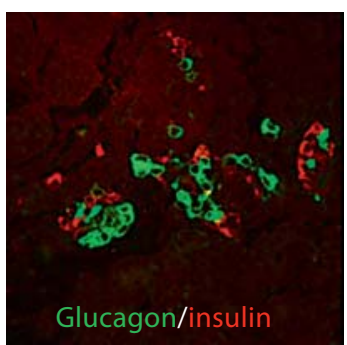

e10

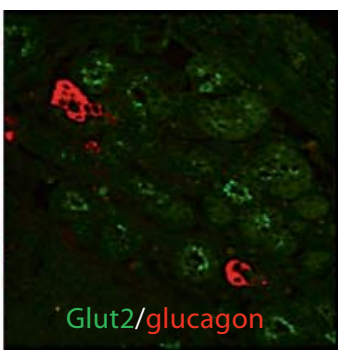

d

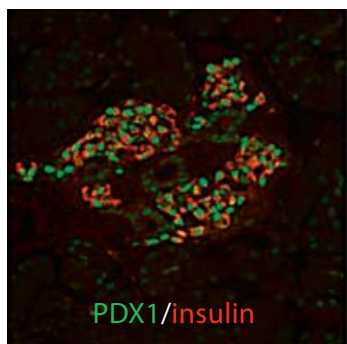

b

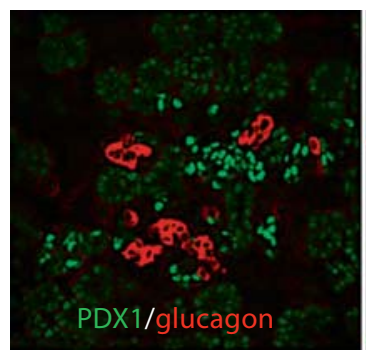

e18

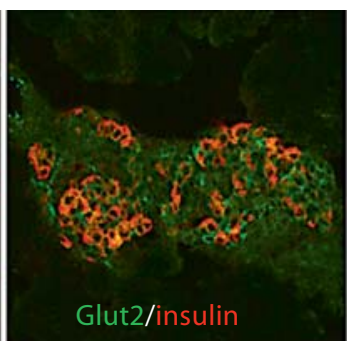

e11.5-13.5
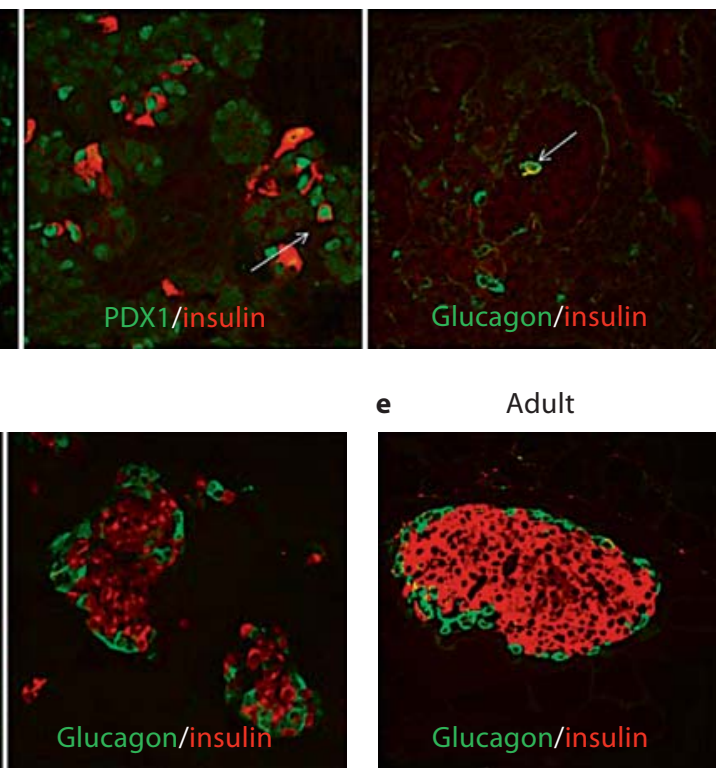

e

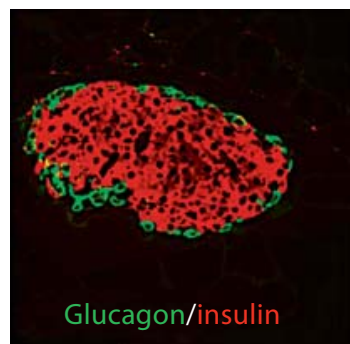

Fig. 2. Temporal endocrine differentiation. Photomicrographs illustrate confocal microscopic images. a The pancreas of an e10 embryo immunostained for PDX-1 (green), glucagon (red), and glucose transporter 2 (Glut2) (green) shows expression of glucagon as the first hormone to appear in the primitive endoderm. b The pancreas of an e11.5-13.5 embryo immunostained with PDX-1 (green), glucagon (red), and insulin (red) shows the presence of co-expressing glucagon insulin cells found during the protodifferentiated state (arrows) followed by the appearance of mature insulin cells at e13.5. c Photomicrograph of sections of pancreas of e15 mice illustrates the presence of insulin or beta cells surrounded by glucagon or alpha cells at these stages of de- velopment. a, b, d PDX-1 immunostaining (green) at various stages shows that at e10.5-e15.5, PDX-1 is expressed throughout the pancreatic epithelium and is subsequently down-regulated in aci$\mathrm{ni}$ and ducts while being maintained in beta cells. a, d Glut 2 immunostaining (green) at various stages shows that at e10, Glut2 is expressed in cells that do not express any other hormone and is subsequently found in the cytoplasm of insulin or beta cells. d, e Beyond e17.5, endocrine cells aggregate into recognizable islets, with insulin or beta cells at their cores and glucagon or alpha cells distributed peripherally in a similar pattern found in adult rodent pancreas $(\mathbf{e})$. progenitor cell population into a mature non-dividing NeuroD+/Isl1+/Pax6+/Ki-67- cell [16]. Following the initiation of the endocrine program, a set of transcription factors is necessary to then convert Ngn3-labelled cells into alpha, beta, delta, and PP cells.

\section{Transcription Factors Found in Cells That Produce}

\section{Each of the Endocrine Hormones}

The second level of branching is directed by another pair of opposing transcription factors: Pax4-Arx [14]. Pax4, a paired box gene, also plays a central role in the differential specification of endocrine precursor cells. It is expressed around e9.5 in both of the pancreatic buds and becomes progressively restricted to beta cells until e15 [21, 22]. Arx, a member of the aristaless-related paired-class homeobox gene family, is restricted to alpha- and beta-cell precursors and delta cells [9]. Arx ap- pears to specify the alpha-cell fate, whereas Pax4 first allows the commitment towards a beta-/delta-cell fate by repressing Arx and subsequently inducing precursor cells towards a beta-cell fate through the inhibition of the delta-cell destiny $[9,22]$. It has been shown that both Pax4 and Arx require the activity of Nkx2.2. Nkx2.2 belongs to the NK class of homeodomain-encoding genes, and its expression is initiated at e9.5 in the dorsal epithelium, becoming progressively restricted to alpha-, beta-, and PP-cell subtypes [23]. In addition, Nkx2.2 and Pax4 control Arx gene activity in committed betacell precursors [24]. Nkx6.1, an additional member of the NK class, is also detectable at e9.5 in both pancreatic buds and becomes specifically restricted to beta cells $[25,26]$. 
Transcription Factors Found in a Specific

Hormone-Producing Cell Type: Maintenance of the

Islet-Cell Subtype

Beta-Cell Lineages

It has been proposed, on the basis of the glucose transporter 2 (Glut2) gene fetal expression pattern [27], that there may be two separate beta-cell lineages: the 'first wave or protodifferentiated' beta cell, also called insulin cell co-expressing glucagon that appears at e10.5, and the 'mature or second transition' beta/insulin cell that appears at e13.5 and persists during adult life (fig. 2).

First Wave. The earliest endocrine cells to appear are multihormonal and co-express glucagon $[25,28]$. Although early studies contested the existence of these cells [29], this point has now been confirmed repeatedly by us [30] and numerous groups [25, 28, 31-33]. Double- and triple-staining studies of early pancreatic buds have shown that the vast majority of the insulin-glucagon coexpressing cells are negative for PDX-1, Nkx6.1 [25], or Pax4 [22], suggesting that these cells derive from a different progenitor cell. They usually appear in clusters surrounded by glucagon cells and express activin [33]. Furthermore, there is some evidence that insulin-glucagon cells proliferate [28], suggesting a contribution to the pool of either glucagon or insulin cells.

Second Transition. During the second transition, mature beta cells arise directly from non-hormonal protodifferentiated epithelial cells that express Glut2, nerve growth factor receptor TrkA, PDX-1, and Nkx6.1 [27, 3436], as well as amyloid polypeptide, PC3/1, PC2, NKx2.2, glucokinase, and MafA [37, 38]. In mature organized insulin cells, PDX-1, which is stabilized by the retinoblastoma protein [39], transactivates the insulin gene and other genes involved in glucose sensing and metabolism such as Glut 2 and glucokinase [27]. Glucose sensing is the initial event in the pathway for glucose-stimulated insulin secretion from the pancreatic insulin cell [40]. PERK (EIF2AK3) expression during fetal life is also required for the differentiation of beta cells and the development of normal islet architecture [41]. Other important transcription factors involved in beta-cell identity are NeuroD and MafA which both activate insulin transcription. MafA is a beta cell-specific transcription factor that binds to the insulin promoter, playing a crucial role in beta-cell maintenance [42]. In addition, MafA interacts with PDX-1 and NeuroD to activate insulin transcription [43]. NeuroD, while not required for endocrine cell differentiation, may be involved in promoting cell cycle exit and has been associated with maturity-onset diabetes of the youth (MODY) in humans (table 2) [5].
Alpha-Cell Lineages

Despite the significant differences between alpha and beta cells, it has been shown that both cells share major similarities [44]. Recent evidence suggests that alpha cells can transdifferentiate into beta cells [45-47], thus it is important to fully understand how alpha cells develop. After the endocrine progenitor develops, another set of opposing transcription factors will direct the development of alpha cells. Arx and forkhead box A2 (FOXA2) are implicated in the initial or terminal differentiation of alpha cells. In addition, FOXA1, Pax6, Brn4, and Isl1 are involved in the preproglucagon transcription and maintaining of alpha-cell function $[48,49]$.

\section{MicroRNAs and Epigenetic Modifications}

During development, the pancreas expresses many small non-coding RNAs called microRNAs (approx. 20 nt). microRNAs are post-transcriptional regulators that are integrated into an RNA-induced silencing complex to repress translation, resulting in gene silencing [50]. Evidence suggests at least 125 microRNAs are involved in pancreatic development. It has been found that microRNAs are important in regulating ductal, exocrine, and endocrine development, particularly beta-cell neogenesis [51].

Recently, epigenetic modification has also been shown to alter the expression of genes involved in beta-cell differentiation. Specifically, histone deacetylases class II (HDAC), which are expressed in the endocrine pancreas, are key regulators in controlling the pancreatic cell lineage by inhibiting beta-cell (HDAC 4, 5, and 9) and deltacell development (HDAC 4 and 5) [52].

\section{Human Pancreatic Development}

In humans, the pancreas develops as a ventral and dorsal outgrowth, first visible at days 25-26 of gestation [53]. The human pancreatic bud elongates into a loose mesenchymal bed [54]. By 35 days of gestation, the ventral pancreatic bud begins to rotate and eventually comes into contact and fuses with the dorsal bud during the 6th week of development or gestational age (wGA) [55-61]. Similar to rodents, the mesenchymal tissue plays an important role in cell fate differentiation [62]. From 8 to $10 \mathrm{wGA}$, pancreatic ducts are surrounded by the mesenchyme and eventually branch and form lobular structures, becoming clearly defined by 11 wGA. Endocrine differentiation has 
been shown to follow a spatial and temporal pattern where the endocrine mass increases from the center of the organ, in central epithelial ducts, toward the periphery in a centrifugal manner [63]. By 9-11 wGA, the mesenchymal tissue contains scattered hormone-negative Ngn3-positive endocrine cells [62], and, similar to rodents, the first endocrine cells have been found to be associated with the ductal epithelium [64]. These endocrine cells are found at a distance away from the mesenchymal tissue, suggesting that the mesenchyme could have a repressive effect on the development of endocrine tissues [63]. The critical window of differentiation of endocrine cells in humans is from 9 to $23 \mathrm{wGA}$ [62]. Assan et al. [65] demonstrated that glucagon cells are the first cells that appear in the fetal pancreas. Glucagon cells are found at 7 wGA [65], followed by insulin, somatostatin, and PP cells at 8-10 wGA [58]. It has also been shown that a subpopulation of primitive endocrine cells that co-express insulin, glucagon, and somatostatin appears at $8 \mathrm{wGA}$. This subset of primitive cells has a low proliferation rate, suggesting that the 'mature endocrine cells' arise from progenitors by differentiation instead of proliferation [63]. Despite the similarity to rodents, human islets and mouse islets differ considerably in architecture and composition in that alpha, beta, and delta cells are dispersed throughout the islet [66].

Single-cell transcriptional analysis from adult islets has identified two populations of cells: larger cells with a dense cytoplasm that constitute the majority of the islet population and distinctly smaller cells. The large mature beta cells express insulin, PDX-1, Glut2, Nkx2.2, Ngn3, Nkx6.1, Pax6, Isl1, and NeuroD [67]. Islets are seen as early as at $11 \mathrm{wGA}$, and vascularized structures appear by 20-23 wGA $[62,68]$. The peak proliferation of glucagon cells occurs at $20 \mathrm{wGA}$, and at $23 \mathrm{wGA}$ for insulin and somatostatin cells. [62]. In contrast to rodents, human fetuses are able to develop a robust insulin response to secretagogues [69].
As studies of the human pancreas are limited, we rely on animal studies to elucidate the progression of pancreatic development. It has been shown that certain mutations seen in animal models can also affect human pancreatic endocrine development, such as mutations in PDX-1 expression, which is associated with pancreatic agenesis and MODY4 (table 2). Similarly, changes in glucokinase activity have also been associated with large islets, highlighting the importance of transcription factors as well as enzymes in human endocrine pancreas differentiation and function [70].

Similar to rodents, studies have shown microRNAs to play a role in targeting genes and transcription factors that are essential to pancreatic development. A total of 212 microRNAs have been found to be expressed in 10-22-week-old fetuses. Four microRNAs have been shown to increase their expression, 35 microRNAs have had decreased expression, and 173 microRNAs remained unchanged [71].

\section{Conclusion}

The development of the endocrine pancreas is regulated at several levels by cell-cell and cell-matrix interactions and locally produced and circulating peptides as well as nutrients that generate diverse intracellular signals. The analysis of mouse loss-of-function phenotypes has represented a powerful tool for the attribution of specific gene functions and has demonstrated the importance of multiple systems in determining pancreatic cell fate determination. However, regardless of all the knowledge gained over the last decade, it has not been possible to successfully develop functioning beta cells from nonpancreatic cells or endocrine precursors. With collective research efforts yielding new information in this field, we hope to be brought closer to generating a cure for diabetes.

\section{References}

1 Unger RH, Dobbs RE, Orci L: Insulin, glucagon, and somatostatin secretion in the regulation of metabolism. Annu Rev Physiol 1978;40:307-343.

-2 Heinis M, Simon MT, Ilc K, Mazure NM, Pouyssegur J, Scharfmann R, Duvillie B: Oxygen tension regulates pancreatic beta-cell differentiation through hypoxia-inducible factor 1alpha. Diabetes 2010;59:662-669.
-3 Fraker CA, Alvarez S, Papadopoulos P, Giraldo J, Gu W, Ricordi C, Inverardi L, Dominguez-Bendala J: Enhanced oxygenation promotes beta-cell differentiation in vitro. Stem Cells 2007;25:3155-3164.

4 Ranjan AK, Joglekar MV, Hardikar AA: Endothelial cells in pancreatic islet development and function. Islets 2009;1:2-9.

5 Jensen J: Gene regulatory factors in pancreatic development. Dev Dynamics 2004;229: 176-200.
6 Kim SK, Hebrok M: Intercellular signals regulating pancreas development and function. Genes Dev 2001;15:111-127.

7 Oliver-Krasinski JM, Stoffers DA: On the origin of the beta cell. Genes Dev 2008;22: 1998-2021.

8 Pictet R, Rutter WJ: Development of the embryonic pancreas; in Steiner DF, Frenkel N (eds): Handbook of Physiology. Washington, American Physiological Society, 1972, pp 25-66. 
-9 Collombat P, Mansouri A, Hecksher-Sorensen J, Serup P, Krull J, Gradwohl G, Gruss P: Opposing actions of Arx and Pax4 in endocrine pancreas development. Genes Dev 2003;17:2591-2603.

-10 Gu G, Dubauskaite J, Melton DA: Direct evidence for the pancreatic lineage: NGN3+ cells are islet progenitors and are distinct from duct progenitors. Development 2002; 129:2447-2457.

-11 Apelqvist A, Li H, Sommer L, Beatus P, Anderson DJ, Honjo T, DeAngelis MH, Lendahl $\mathrm{U}$, Edlund $\mathrm{H}$ : Notch signaling controls pancreatic cell differentiation. Nature 1999;400: 877-881.

$\checkmark 12$ Seymour PA, Freude KK, Tran MN, Mayes EE, Jensen J, Kist R, Scherer G, Sander M: SOX9 is required for maintenance of the pancreatic progenitor cell pool. Proc Natl Acad Sci USA 2007;104:1865-1870.

$\checkmark 13$ Hua H, Zhang YQ, Dabernat S, Kritzik M, Dietz D, Sterling L, Sarvetnick N: BMP4 regulates pancreatic progenitor cell expansion through Id2. J Biol Chem 2006;281:1357413580.

14 Zhou JX, Brusch L, Huang S: Predicting pancreas cell fate decisions and reprogramming with a hierarchical multi-attractor model. PLoS One 2011;6:e14752.

-15 Gradwohl G, Dierich A, LeMeur M, Guillemot F: Neurogenin 3 is required for the development of the four endocrine cell lineages of the pancreas. Proc Natl Acad Sci USA 2000; 97:1607-1611.

-16 Jensen J, Heller R, Funder-Nielsen T, Pedersen E, Lindsell C, Weinmaster G, Madsen OD, Serup P: Independent development of pancreatic alpha and beta-cells from neurogenin3-expressing precursors: a role for notch pathway in repression of premature differentiation. Diabetes 2000;49:163-176.

-17 Kawaguchi Y, Cooper B, Gannon M, Ray M, MacDonald RJ, Wright CV: The role of the transcriptional regulator Ptf1a in converting intestinal to pancreatic progenitors. Nat Genetics 2002;32:128-134.

-18 Miyatsuka T, Kosaka Y, Kim H, German MS: Neurogenin 3 inhibits proliferation in endocrine progenitors by inducing Cdknla. Proc Natl Acad Sci USA 2011;108:185-190.

$\checkmark 19$ Kim SY, Rane SG: The Cdk4-E2f1 pathway regulates early pancreas development by targeting Pdx1+ progenitors and Ngn3+ endocrine precursors. Development 2011;138: 1903-1912.

-20 Smith SB, Qu HQ, Taleb N, Kishimoto NY, Scheel DW, Lu Y, Patch AM, Grabs R, Wang J, Lynn FC, Miyatsuka T, Mitchell J, Seerke R, Desir J, Eijnden SV, Abramowicz M, Kacet N, Weill J, Renard ME, Gentile M, Hansen I, Dewar K, Hattersley AT, Wang R, Wilson ME, Johnson JD, Polychronakos C, German MS: Rfx6 directs islet formation and insulin production in mice and humans. Nature 2010;463:775-780.

-21 Smith SB, Ee HC, Conners JR, German MS: Paired-homeodomain transcription factor
PAX4 acts as a transcriptional repressor in early pancreatic development. Mol Cell Biol 1999; 19:8272-8280.

22 Sosa-Pineda B: The gene Pax4 is an essential regulator of pancreatic beta-cell development. Mol Cells 2004;18:289-294.

23 Sussel L, Kalamaras J, Hartigan-O’Connor DJ, Meneses JJ, Pedersen RA, Rubenstein JL, German MS: Mice lacking the homeodomain transcription factor $\mathrm{Nkx} 2.2$ have diabetes due to arrested differentiation of pancreatic beta cells. Development 1998;125:2213-2221.

24 Kordowich S, Collombat P, Mansouri A, Serup $\mathrm{P}$ : Arx and Nkx2.2 compound deficiency redirects pancreatic alpha- and beta-cell differentiation to a somatostatin/ghrelin co-expressing cell lineage. BMC Dev Biol 2011;11:52.

25 Oster A, Jensen J, Edlund H, Larsson LI: Homeobox gene product Nkx 6.1 immunoreactivity in nuclei of endocrine cells of rat and mouse stomach. J Histochem Cytochem 1998;46:717-721.

26 Sander M, Paydar S, Ericson J, Briscoe J, Berber E, German M, Jessell TM, Rubenstein JL: Ventral neural patterning by Nkx homeobox genes: Nkx6.1 controls somatic motor neuron and ventral interneuron fates. Genes Dev 2000;14:2134-2139.

27 Pang K, Mukonoweshuro C, Wong GG: Beta cells arise from glucose transporter type 2 (Glut2)-expressing epithelial cells of the developing rat pancreas. Proc Natl Acad Sci USA 1994;91:9559-9563.

28 Jackerott M, Oster A, Larsson LI: PYY in developing murine islet cells: comparisons to development of islet hormones, NPY, and BrdU incorporation. J Histochem Cytochem 1996;44:809-817.

29 Herrera PL, Huarte J, Sanvito F, Meda P, Orci L, Vassalli JD: Embryogenesis of the murine endocrine pancreas; early expression of the pancreatic polypeptide gene. Development 1991;113:1257-1265.

30 Vuguin PM, Kedees MH, Cui L, Guz Y, Gelling RW, Nejathaim M, Charron MJ, Teitelman G: Ablation of the glucagon receptor gene increases fetal lethality and produces alterations in islet development and maturation. Endocrinology 2006;147:3995-4006.

-31 De Krijger RR, Aanstoot HJ, Kranenburg G, Reinhard M, Visser WJ, Bruining GJ: The midgestational human fetal pancreas contains cells co-expressing islet hormones. Dev Biol 1992;153:368-375.

32 Lukinius A, Ericsson JL, Grimelius L, Korsgren O: Ultrastructural studies of the ontogeny of fetal human and porcine endocrine pancreas, with special reference to colocalization of the four major islet hormones. Dev Biol 1992;153:376-385.

33 Furukawa M, Eto Y, Kojima I: Expression of immunoreactive activin $\mathrm{A}$ in fetal rat pancreas. Endocr J 1995;42:63-68.

34 Jonsson J, Carlsson L, Edlund T, Edlund H: Insulin-promoter-factor 1 is required for pancreas development in mice. Nature 1994; 371:606-609.
35 Offield MF, Jetton TL, Labosky PA, Ray M, Stein R, Magnuson MA, Hogan BL, Wright CV: PDX-1 is required for pancreatic outgrowth and differentiation of the rostral duodenum. Development 1996;122:983-995.

- 36 Scharfmann R, Czernichow P: Differentiation and growth of pancreatic beta cells. Diabetes Metab 1996;22:223-228.

37 Matsuoka TA, Zhao L, Artner I, Jarrett HW, Friedman D, Means A, Stein R: Members of the large Maf transcription family regulate insulin gene transcription in islet beta cells. Mol Cell Biol 2003;23:6049-6062.

38 Artner I, Le Lay J, Hang Y, Elghazi L, Schisler JC, Henderson E, Sosa-Pineda B, Stein R: MafB: an activator of the glucagon gene expressed in developing islet alpha- and betacells. Diabetes 2006;55:297-304.

- 39 Kim YC, Kim SY, Mellado-Gil JM, Yadav H, Neidermyer W, Kamaraju AK, Rane SG: RB regulates pancreas development by stabilizing Pdx1. EMBO J 2011;30:1563-1576.

40 Cerf ME: High fat diet modulation of glucose sensing in the beta-cell. Med Sci Monit 2007; 13:RA12-17.

41 Zhang W, Feng D, Li Y, Iida K, McGrath B, Cavener DR: PERK EIF2AK3 control of pancreatic beta cell differentiation and proliferation is required for postnatal glucose homeostasis. Cell Metab 2006;4:491-497.

42 Kataoka K, Han SI, Shioda S, Hirai M, Nishizawa M, Handa H: MafA is a glucoseregulated and pancreatic beta-cell-specific transcriptional activator for the insulin gene. J Biol Chem 2002;277:49903-49910.

43 Aramata S, Han SI, Kataoka K: Roles and regulation of transcription factor mafA in islet beta-cells. Endocr J 2007;54:659-666.

44 Wang J, Webb G, Cao Y, Steiner DF: Contrasting patterns of expression of transcription factors in pancreatic alpha and beta cells. Proc Natl Acad Sci USA 2003;100: 12660-12665.

45 Lu J, Herrera PL, Carreira C, Bonnavion R, Seigne C, Calender A, Bertolino P, Zhang CX: Alpha cell-specific Men1 ablation triggers the transdifferentiation of glucagon-expressing cells and insulinoma development. Gastroenterology 2010;138:1954-1965.

46 Thorel F, Nepote V, Avril I, Kohno K, Desgraz R, Chera S, Herrera PL: Conversion of adult pancreatic alpha-cells to beta-cells after extreme beta-cell loss. Nature 2010.

47 Sangan CB, Tosh D: A new paradigm in cell therapy for diabetes: turning pancreatic alpha-cells into beta-cells. Bioessays 2010;32: 881-884.

48 Bramswig NC, Kaestner KH: Transcriptional regulation of alpha-cell differentiation. Diabetes Obes Metab 2011;13(suppl 1):1320.

49 Gosmain Y, Marthinet E, Cheyssac C, Guerardel A, Mamin A, Katz LS, Bouzakri K, Philippe J: Pax6 controls the expression of critical genes involved in pancreatic \{alpha\} cell differentiation and function. J Biol Chem 2010;285:33381-33393. 
50 Ambros V: The functions of animal microRNAs. Nature 2004;431:350-355.

-51 Lynn FC, Skewes-Cox P, Kosaka Y, McManus MT, Harfe BD, German MS: MicroRNA expression is required for pancreatic islet cell genesis in the mouse. Diabetes 2007;56: 2938-2945.

- 52 Lenoir O, Flosseau K, Ma FX, Blondeau B, Mai A, Bassel-Duby R, Ravassard P, Olson EN, Haumaitre C, Scharfmann R: Specific control of pancreatic endocrine beta- and delta-cell mass by class IIa histone deacetylases HDAC4, HDAC5, and HDAC9. Diabetes 2011;60:2861-2871.

53 Piper K, Ball SG, Turnpenny LW, Brickwood S, Wilson DI, Hanley NA: Beta-cell differentiation during human development does not rely on nestin-positive precursors: implications for stem cell-derived replacement therapy. Diabetologia 2002;45:1045-1047.

-54 Piper K, Brickwood S, Turnpenny LW, Cameron IT, Ball SG, Wilson DI, Hanley NA: Beta cell differentiation during early human pancreas development. J Endocrinol 2004;181: $11-23$.

55 Falin LI: The development and cytodifferentiation of the islets of Langerhans in human embryos and foetuses. Acta Anat (Basel) 1967;68:147-168.

56 Orci L, Perrelet A, Like AA: Fenestrae in the rough endoplasmic reticulum of the exocrine pancreatic cells. J Cell Biol 1972;55: 245-249.

57 Like AA, Orci L: Embryogenesis of the human pancreatic islets: a light and electron microscopic study. Diabetes 1972;21:511-534.

-58 Stefan Y, Grasso S, Perrelet A, Orci L: A quantitative immunofluorescent study of the endocrine cell populations in the developing human pancreas. Diabetes 1983;32: 293-301.

59 Clark A, Grant AM: Quantitative morphology of endocrine cells in human fetal pancreas. Diabetologia 1983;25:31-35.

-60 Fukayama M, Ogawa M, Hayashi Y, Koike M: Development of human pancreas. Immunohistochemical study of fetal pancreatic secretory proteins. Differentiation 1986;31: 127-133.

61 Bocian-Sobkowska J, Zabel M, Wozniak W, Surdyk-Zasada J: Prenatal development of the human pancreatic islets. Immunocytochemical identification of insulin-, glucagon-, somatostatin- and pancreatic polypeptide-containing cells. Folia Histochem Cytobiol 1997;35:151-154.

-62 Sarkar SA, Kobberup S, Wong R, Lopez AD, Quayum N, Still T, Kutchma A, Jensen JN, Gianani R, Beattie GM, Jensen J, Hayek A, Hutton JC: Global gene expression profiling and histochemical analysis of the developing human fetal pancreas. Diabetologia 2008; 51: 285-297.

-63 Polak M, Bouchareb-Banaei L, Scharfmann R, Czernichow P: Early pattern of differentiation in the human pancreas. Diabetes 2000;49:225-232.
-64 Meier JJ, Kohler CU, Alkhatib B, Sergi C, Junker T, Klein HH, Schmidt WE, Fritsch $\mathrm{H}$ : Beta-cell development and turnover during prenatal life in humans. Eur J Endocrinol 2010;162:559-568.

- 65 Assan R, Boillot J: Pancreatic glucagon and glucagon-like material in tissues and plasma from human fetuses 6-26 weeks old. Pathol Biol (Paris) 1973;21:149-155.

66 Brissova M, Fowler MJ, Nicholson WE, Chu A, Hirshberg B, Harlan DM, Powers AC: Assessment of human pancreatic islet architecture and composition by laser scanning confocal microscopy. J Histochem Cytochem 2005;53:1087-1097.

67 Chiang MK, Melton DA: Single-cell transcript analysis of pancreas development. Dev Cell 2003;4:383-393.

68 Jeon J, Correa-Medina M, Ricordi C, Edlund H, Diez JA: Endocrine cell clustering during human pancreas development. J Histochem Cytochem 2009;57:811-824.

-69 Nicolini U, Hubinont C, Santolaya J, Fisk $\mathrm{NM}$, Rodeck CH: Effects of fetal intravenous glucose challenge in normal and growth retarded fetuses. Horm Metab Res 1990;22: 426-430.

70 Kassem S, Bhandari S, Rodriguez-Bada P, Motaghedi R, Heyman M, Garcia-Gimeno MA, Cobo-Vuilleumier N, Sanz P, Maclaren NK, Rahier J, Glaser B, Cuesta-Munoz AL: Large islets, beta-cell proliferation, and a glucokinase mutation. N Engl J Med 2010; 362:1348-1350.

71 Rosero S, Bravo-Egana V, Jiang Z, Khuri S, Tsinoremas N, Klein D, Sabates E, CorreaMedina M, Ricordi C, Dominguez-Bendala J, Diez J, Pastori RL: MicroRNA signature of the human developing pancreas. BMC Genomics 2010;11:509.

72 Harrison KA, Thaler J, Pfaff SL, Gu H, Kehrl JH: Pancreas dorsal lobe agenesis and abnormal islets of Langerhans in Hlxb9-deficient mice. Nat Genet 1999;23:71-75.

73 Ahlgren U, Jonsson J, Jonsson L, Simu K, Edlund H: Beta-cell-specific inactivation of the mouse Ipf1/Pdx 1 gene results in loss of the beta-cell phenotype and maturity onset diabetes. Genes Dev 1998;12:1763-1768.

74 Stoffers DA, Ferrer J, Clarke WL, Habener JF: Early-onset type-II diabetes mellitus (MODY4) linked to IPF1. Nat Genet 1997;17: 138-139.

75 Ahlgren U, Pfaff SL, Jessell TM, Edlund T, Edlund $\mathrm{H}$ : Independent requirement for ISL1 in formation of pancreatic mesenchyme and islet cells. Nature 1997;385:257-260.

76 Shimomura H, Sanke T, Hanabusa T, Tsunoda K, Furuta H, Nanjo K: Nonsense mutation of islet-1 gene (Q310X) found in a type 2 diabetic patient with a strong family history. Diabetes 2000;49:1597-1600.

-77 Dubois CL, Shih HP, Seymour PA, Patel NA, Behrmann JM, Ngo V, Sander M: Sox9-haploinsufficiency causes glucose intolerance in mice. PloS One 2011;6:e23131.
St-Onge L, Sosa-Pineda B, Chowdhury K, Mansouri A, Gruss P: Pax6 is required for differentiation of glucagon-producing alpha-cells in mouse pancreas. Nature 1997; 387:406-409.

79 Ashery-Padan R, Zhou X, Marquardt T, Herrera P, Toube L, Berry A, Gruss P: Conditional inactivation of Pax6 in the pancreas causes early onset of diabetes. Dev Biol 2004;269: 479-488.

80 Sosa-Pineda B, Chowdhury K, Torres M, Oliver G, Gruss P: The Pax4 gene is essential for differentiation of insulin-producing beta cells in the mammalian pancreas. Nature 1997;386:399-402.

81 Wang J, Elghazi L, Parker SE, Kizilocak H, Asano M, Sussel L, Sosa-Pineda B: The concerted activities of Pax4 and Nkx2.2 are essential to initiate pancreatic beta-cell differentiation. Dev Biol 2004;266:178-189.

82 Rubio-Cabezas O, Minton JA, Kantor I, Williams D, Ellard S, Hattersley AT: Homozygous mutations in NEUROD1 are responsible for a novel syndrome of permanent neonatal diabetes and neurological abnormalities. Diabetes 2010;59:2326-2331.

83 Naya FJ, Huang HP, Qiu Y, Mutoh H, DeMayo FJ, Leiter AB, Tsai MJ: Diabetes, defective pancreatic morphogenesis, and abnormal enteroendocrine differentiation in BETA2/neuroD-deficient mice. Genes Dev 1997;11:2323-2334.

84 Itoh M, Takizawa Y, Hanai S, Okazaki S, Miyata R, Inoue T, Akashi T, Hayashi M, Goto Y: Partial loss of pancreas endocrine and exocrine cells of human ARX-null mutation: consideration of pancreas differentiation. Differentiation 2010;80:118-122.

85 Collombat P, Hecksher-Sorensen J, Krull J, Berger J, Riedel D, Herrera PL, Serup P, Mansouri A: Embryonic endocrine pancreas and mature beta cells acquire alpha and PP cell phenotypes upon Arx misexpression. J Clin Invest 2007;117:961-970.

86 Krapp A, Knofler M, Ledermann B, Burki K, Berney C, Zoerkler N, Hagenbuchle O, Wellauer PK: The bHLH protein PTF1-p48 is essential for the formation of the exocrine and the correct spatial organization of the endocrine pancreas. Genes Dev 1998;12: 3752-3763.

87 Fukuda A, Kawaguchi Y, Furuyama K, Kodama S, Horiguchi M, Kuhara T, Kawaguchi M, Terao M, Doi R, Wright CV, Hoshino M, Chiba T, Uemoto S: Reduction of Ptfla gene dosage causes pancreatic hypoplasia and diabetes in mice. Diabetes 2008;57:2421-2431.

88 Sellick GS, Barker KT, Stolte-Dijkstra I, Fleischmann C, Coleman RJ, Garrett C, Gloyn AL, Edghill EL, Hattersley AT, Wellauer PK, Goodwin G, Houlston RS: Mutations in PTF1A cause pancreatic and cerebellar agenesis. Nat Genet 2004;36:1301-1305.

89 Artner I, Blanchi B, Raum JC, Guo M, Kaneko T, Cordes S, Sieweke M, Stein R: MafB is required for islet beta cell maturation. Proc Natl Acad Sci USA 2007;104:3853-3858. 